\title{
Protection from Arsenic Induced Hyperglycemia by a Traditional Plant - A Preliminary Study
}

\author{
Shaba Parveen ${ }^{1}$, Sujaffar Hossain Molla ${ }^{1}$, Tapan Kumar Ghosh ${ }^{2}$ and Alok Chattopadhyay ${ }^{1}$ \\ ${ }^{1}$ Department of Physiology, Harimohan Ghose College, Kolkata, India
}

${ }^{2}$ Department of Physiology, City College, Raja Rammohan Sarani, Kolkata, India

\begin{abstract}
Arsenic contamination in water is a major threat to human health and among the health hazards hyperglycemia is important. The current investigation was planned to find some remedial treatment of arsenic induced hyperglycemia by dietary supplementation of a traditional plant. This study was performed for a period of 30 days on adult male Wistar rats weighing 120-140 g. They were divided into three equal groups $(n=6)$ : Group Control $(C)$, normal saline administered, Treatment Group 1 (T1), arsenic trioxide fed at the dose of $3 \mathrm{mg} / \mathrm{kg} / \mathrm{day}$ for 30 days; and Treatment Group 2 (T2), arsenic trioxide at the dose of $3 \mathrm{mg} / \mathrm{kg} / \mathrm{day}$ for 30 days along with powder of leaves of Costus igneus fed at the dose of $500 \mathrm{mg} / \mathrm{kg} / \mathrm{day}$ for the last 15 days of arsenic treatment. The body weights and blood sugar levels were recorded on Days 1, 15 and 30 . The animals were sacrificed on the $31^{\text {st }}$ day and pancreas was collected for histological study of islets cells. The body weights of both the groups T1 and T2 decreased significantly $\left({ }^{*} p<0.05\right)$ after 15 days of arsenic treatment. A significant increase in body weight of $\mathrm{T} 2$ was found in the next 15 days of Costus supplementation in comparison to T1. The blood sugar levels of both T1and T2 increased significantly $\left({ }^{*} \mathrm{p}<0.05\right)$ after 15 days of treatment but it was reduced significantly in T2 after the next 15 days of Costus supplementation. The histology of the pancreatic islets cells in T1 illustrated that larger number of islet cells shrunken with lower number of cell counts in comparison to C. However, in T2, cell counts and morphology was restored significantly by Costus supplementation demonstrating that Costus igneus may be an effective agent in protection from arsenic induced hyperglycemia. From these preliminary findings further studies are warranted to elucidate the molecular mechanism of this plant's antihyperglycemic action.
\end{abstract}

Keywords: Arsenic; Costus igneus; Blood sugar; Hyperglycemia; Male rat

\section{Introduction}

India accounts for the largest number of people living below poverty line according to the World Bank. Majority of the inhabitants consume groundwater from dug wells and tube wells especially in West Bengal and its adjoining areas. The municipal water supply is polluted with arsenic rich iron oxyhydrides [1]. Chronic effects of arsenic include oxidative stress, mitochondrial dysfunction, liver damage and impaired glycemic control [2]. According to several survey reports, exposure to inorganic arsenic compounds may be associated with development of diabetes mellitus [3-7]. According to an Indian daily, India ranks among the top three countries in the world for the prevalence of diabetes. For an underdeveloped country like India, more than half of the population could afford the remedial drugs and depend generally on medicinal plants. Of which, a well-known medicinal plant, namely, Costus igneus or insulin plant has been reported to lower blood glucose levels on consumption of its leaves by diabetic patients $[8,9]$. It is called the magic cure for diabetes. Various researches reveal its different components like carbohydrates, triterpenoids, proteins, alkaloids, tannins, saponins, flavonoids, steroid and appreciable amount of trace elements [10]. Moreover, it contains an orally active insulin like protein (ILP) having potent hypoglycemic activity [11]

The current study is an attempt to protect the rural population from arsenic contaminated groundwater induced hyperglycemia in a cost effective and natural way. In order to accomplish the motive in our preliminary investigation we have studied the following parameters: body weight, blood sugar level, histological study of pancreas and islet cell count on male albino rats.

\section{Materials and Methods}

\section{Animals}

The investigation was conducted after obtaining approval from
Institutional Animal Ethical Committee for Animal Experimentation (Ref. no. HMGC-/IAEC/M.R-2). Male albino rats aged 100-120 days of Wistar strains were obtained from, and maintained in, the animal house, Department of Physiology, Harimohan Ghose College, Kolkata, West Bengal, India. The animals weighed 120-140 g and had access to food and water ad libitum. They were kept at a temperature of 28 $\pm 4^{\circ} \mathrm{C}$. The lighting schedule was maintained at $12 \mathrm{~h}$ of light per day, and the rats were acclimatized for 3 days before the beginning of the experiment.

\section{Preparation of the plant product}

The leaves of the insulin plant or Costus igneus were obtained from the campus of University of Calcutta, Department of Home Science in August, 2015 and authentication of the plant was done by the Department of Botany, University of Calcutta. The leaves were shade dried, grind in pestle and mortar and passed through sieve and stored in airtight container at refrigeration temperature $\left(4^{\circ} \mathrm{C}\right)$ before use.

\section{Treatment schedule}

The study was carried out for the period of 30 days. The animals were divided into three equal groups with six animals in each group.

*Corresponding author: Dr. Alok Chattopadhyay, Asstistant Professor and Head, Department of Physiology, Harimohan Ghose College, J206, Paharpur Road, Kolkata 700024, India, Tel: +91 332469 3641; +09830521502; Fax: +91332489 5499; E-mail: alokc1972@yahoo.co.in; alokc1972@gmail.com

Received December 26, 2017; Accepted January 30, 2017; Published February 05, 2017

Citation: Parveen S, Molla SH, Ghosh TK, Chattopadhyay A (2017) Protection from Arsenic Induced Hyperglycemia by a Traditional Plant - A Preliminary Study. Hepatol Pancreat Sci 1: 102.

Copyright: (c) 2017 Parveen S, et al. This is an open-access article distributed under the terms of the Creative Commons Attribution License, which permits unrestricted use, distribution, and reproduction in any medium, provided the original author and source are credited. 
Groups were designated as Group Control (C), normal mammalian saline fed; Group Treated 1 (T1), arsenic trioxide (Sigma Chemical Co., St. Louis, MD, USA) administered orally at the dose of $3 \mathrm{mg} / \mathrm{kg}$ body weight/day which is within the range of $\mathrm{LD}_{50}$ of a $70 \mathrm{~kg}$ body weight human $(1-4 \mathrm{mg} / \mathrm{kg})$ and less than one-thirteenth of $\mathrm{LD}_{50}$ value of rats (40 mg/kg) for 30 days [12-14]; and Group Treated 2 (T2), arsenic trioxide at the dose of $3 \mathrm{mg} / \mathrm{kg}$ body weight/day for 30 days along with powder of the leaves of Costus igneus at the dose of $500 \mathrm{mg} / \mathrm{kg}$ body weight/day [7] forcibly fed for the last 15 days of arsenic treatment.

\section{Measurement of body weight}

The body weight of the experimental animals of all the three groups was recorded on Day 1, Day 15 and Day 30 to analyze the effects.

\section{Assessment of blood sugar level}

The blood sugar levels (BSL) of Group C, Group T1 and Group T2 were recorded on Day 1, Day 15 and Day 30 by Glucose-Oxidase Peroxidase kit in protein free supernatant $[15,16]$ provided by Sigma Aldrich Corporation, USA.

Histological study: After the treatment period was over, the animals were sacrificed following ethical procedures and protocols. The pancreas was collected and preserved in Bouin's solution for hematoxylin eosin staining. The tissues were observed and studied under microscope. The alterations in the morphology were taken under consideration. Furthermore, variations in the islets cell count were evaluated [13].

\section{Statistical analysis}

All values were expressed as mean \pm SEM. Data were analyzed by ANOVA (model 1 or fixed model) followed by Student's two tailed ' $t$ ' test [17] to test for differences between control and treated experimental groups. Differences were considered significant when $\left({ }^{*} \mathrm{p}<0.05\right)$.

\section{Results}

No significant difference in body weight was observed between initial, Day 15 and Day 30 of treatment in Group C rats, whereas the body weight of rats of Group T1 were decreased significantly on both Day 15 and Day 30 of treatment period compared to initial value $\left({ }^{\star} \mathrm{p}<0.05\right)$.On the other hand, the body weight of Costus supplemented rats (Group T2) was decreased significantly $\left({ }^{*} \mathrm{p}<0.05\right)$ after 15 days but it also recovered to normal after 30 days in comparison to initial value (Figure 1). The BSL of Group C showed no significant difference on Day 15 and Day 30 from initial value. In Group T1, BSL were elevated significantly on Day 15 and Day 30 as well in comparison to initial value $\left({ }^{*} \mathrm{p}<0.05\right)$. Conversely, Group T2 had significantly elevated BSL on day $15\left({ }^{*} \mathrm{p}<0.05\right)$, but the level reduced almost to initial value on Day 30 , as there was no significant difference in BSL between initial and Day 30 values (Figure 2). Histological study of pancreas demonstrated large number of islet cells in Group C and reduction in cell size in Group T1. The reduced cell morphology was restored to some extent in Group T2 (Figures 3a-3c). The islet cell count was decreased significantly in Group T1 compared with Group $\mathrm{C}\left({ }^{*} \mathrm{p}<0.05\right)$ whereas this value improved in Group T2 as there was no significant difference in cell count between Group C and Group T2 (Figure 4).

\section{Discussion}

The global problem of arsenic contamination in drinking water is imposing severe threat to human health [18-20] and several reports show development of diabetes mellitus is associated with arsenic

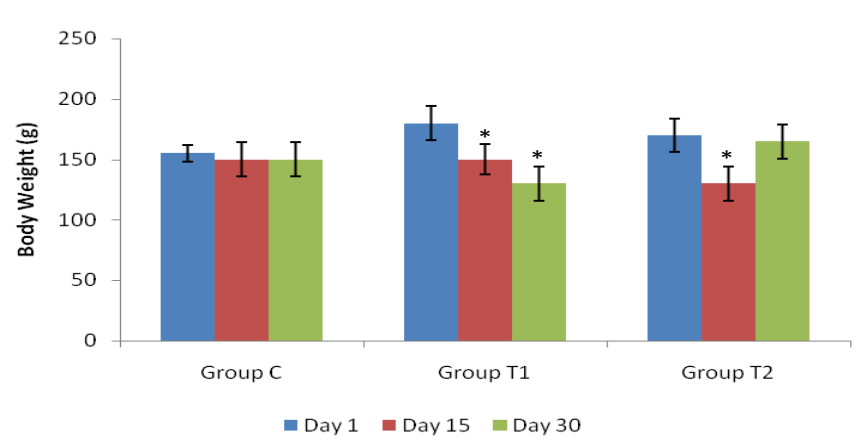

Figure 1: Effect of arsenic trioxide at the dose of $3 \mathrm{mg} / \mathrm{kg} /$ day and simultaneous Costus leaves supplementation at the dose of $500 \mathrm{mg} / \mathrm{kg} /$ day on body weight (g) of male rats at three different intervals.

[Values marked with asterisks are significantly different from corresponding initial values (values are mean + SEM of 6 rats/group)]

[ANOVA followed by Student's two tailed ' $t$ ' test, where * $\mathrm{p}<0.05$ ]

Group Control(C) normal mammalian saline treated

Group Treated1 (T1) arsenic trioxide fed at the dose of $3 \mathrm{mg} / \mathrm{kg} /$ day for 30 days

Group Treated2 (T2) arsenic trioxide fed at the dose of $3 \mathrm{mg} / \mathrm{kg} / \mathrm{day}$ for 30 days and Costus supplementation at the dose of $500 \mathrm{mg} / \mathrm{kg} /$ day for the last 15 days of arsenic treatment.

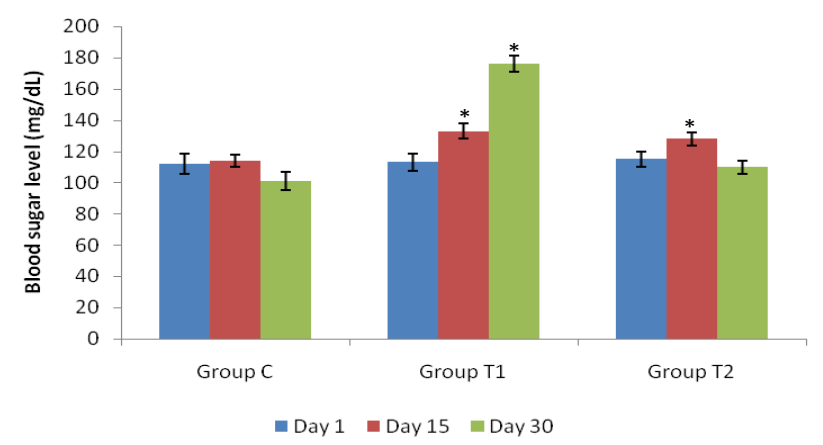

Figure 2: Effect of arsenic trioxide at the dose of $3 \mathrm{mg} / \mathrm{kg} / \mathrm{day}$ and simultaneous Costus leaves supplementation at the dose of $500 \mathrm{mg} / \mathrm{kg} / \mathrm{day}$ on blood sugar level $(\mathrm{mg} / \mathrm{dL})$ of male rats at three different intervals.

[Values marked with asterisks are significantly different from control values (values are mean + SEM of 6 rats/group)]

[ANOVA followed by Student's two tailed 't' test, where * $\mathrm{p}<0.05$ ]

Group Control(C) normal mammalian saline treated

Group Treated1 (T1) arsenic trioxide fed at the dose of $3 \mathrm{mg} / \mathrm{kg} / \mathrm{day}$ for 30 days

Group Treated2 (T2) arsenic trioxide fed at the dose of $3 \mathrm{mg} / \mathrm{kg} / \mathrm{day}$ for 30 days and simultaneous Costus leaves supplementation at the dose of 500 $\mathrm{mg} / \mathrm{kg} /$ day for the last 15 days of arsenic treatment.

exposure [21-23]. Since, most of the arsenic affected populations of South Asia specially Bangladesh and West Bengal of India are belonging to economically weaker section of the society $[1,20]$, expensive medicines for treatment of diabetes are unaffordable for them. As a result, alternative cheaper mode of treatment is in urgent need for these people.

In the present study, simultaneous supplementation of the leaves of Costus igneus to arsenic induced hyperglycemic rats resulted in 
Citation: Parveen S, Molla SH, Ghosh TK, Chattopadhyay A (2017) Protection from Arsenic Induced Hyperglycemia by a Traditional Plant - A Preliminary Study. Hepatol Pancreat Sci 1: 102.

Page 3 of 4

(a)

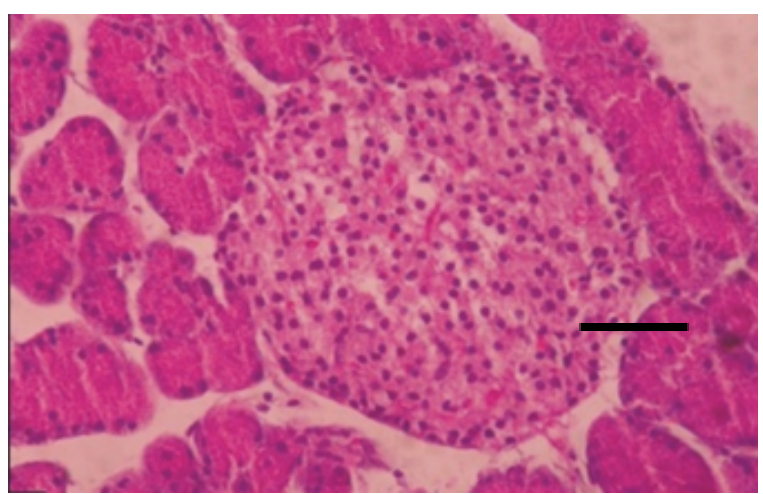

b)

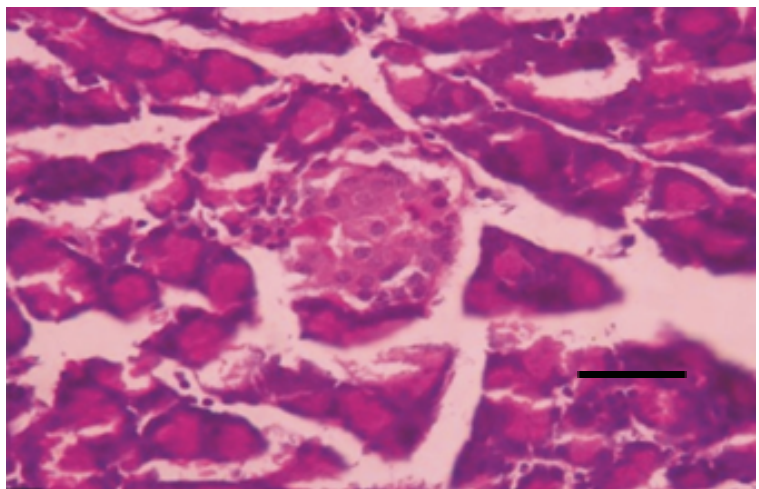

(c)

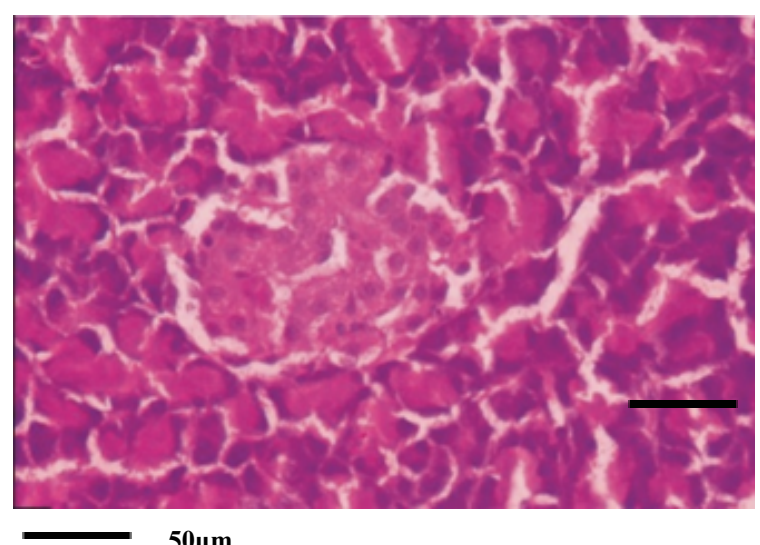

Figure 3: Photomicrograph of the pancreatic islets cell histology of the (a) control group rats (Group C); (b) rats treated with arsenic trioxide at the dose of $3 \mathrm{mg} / \mathrm{kg} /$ day for 30 days (Group T1); (c) rats treated with arsenic trioxide at the dose of $3 \mathrm{mg} / \mathrm{kg} /$ day for 30 days and simultaneous supplementation of leaves of Costus igneus at the dose $500 \mathrm{mg} / \mathrm{kg} / \mathrm{day}$ from Day 15 to Day 30 (Group T2) of arsenic treatment.

improvement from disease conditions. Though there were very few scientific documentation regarding the hypoglycemic action of Costus $[7,24]$, a section of hyperglycemic Indian population used to eat this leaf to keep their blood glucose low $[6,25]$.

The body weights of arsenic treated group (T1) decreased significantly which is a general manifestation of diabetes mellitus occurring due to excessive breakdown of tissue proteins [26]. Costus supplemented rats retarded their weight loss (Figure 1) indicating an improved metabolic status from diabetes. The reduction of blood glucose concentration in simultaneous Costus supplemented group (T2)

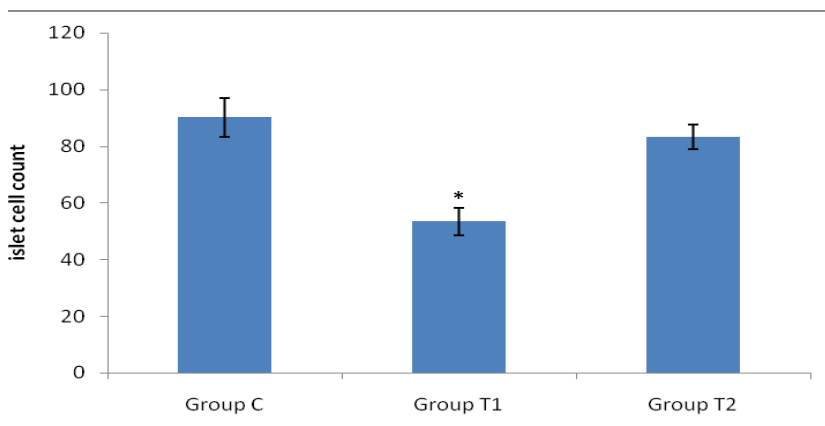

Figure 4: Effect of arsenic trioxide at the dose of $3 \mathrm{mg} / \mathrm{kg} /$ day and simultaneous supplementation of leaves of Costus igneus at the dose $500 \mathrm{mg} / \mathrm{kg} /$ day on islet cell count of pancreas among the groups of rats.

[Value marked with asterisk is significantly different from control value (values are mean + SEM of 6 rats/group)]

[ANOVA followed by Student's two tailed ' $t$ ' test, where * $p<0.05$ ]

Group Control(C) normal mammalian saline treatment

Group Treated1 (T1) arsenic trioxide fed at the dose of 3mg/kg/day for 30 days

Group Treated2 (T2) arsenic trioxide fed at the dose of 3mg/kg/day for 30days and simultaneous supplementation of leaves of Costus at the dose of $500 \mathrm{mg} /$ $\mathrm{kg} /$ day for the last 15 days of arsenic treatment.

from the hyperglycemic level of T1 signifies a protective effect of this plant from diabetes which is in agreement with the previous findings [7]. Moreover, arsenic induced hyperglycemia is possibly due to severe damage to the pancreas $[27,28]$ evident by shrunken type morphology of islet cells in Group T1 [Photomicrograph 3(b)] in comparison to control pancreatic islet cells [Photomicrograph 3(a)]. Costus supplementation improved the cell morphology [Photomicrograph $3(\mathrm{c})]$. The histological feature is also reflected in islet cell counts (Figure 4) which shows a significant increase in count in T2 compared to $\mathrm{T} 1$ indicating the hypoglycemic action of Costus to be mediated by improving pancreatic endocrine status.

The exact mechanism of action of this plant product on combating hyperglycemia cannot be determined from this preliminary investigation. Nevertheless, use of this plant as an alternative medicine by the arsenic exposed diabetic people may be encouraged as it is easily available, cheap and is proved to be beneficial. Future studies to elucidate the molecular mechanism of its action are urgently needed to establish the anti-diabetic potential of this plant material at least against arsenic induced hyperglycemia.

\section{Acknowledgement}

The authors express their sincere gratitude to Prof. S. Dutta (De), Department of Home Science and Prof. S. Gangopadhyay, Department of Physiology, University of Calcutta; Dr. S. Mukherjee, Head, Department of Physiology, Serampore College for their cooperation, encouragement and infrastructural support. The authors also thankfully acknowledge Teacher-in-Charge, Harimohan Ghose College Kolkata.

\section{Conflict of Interest}

Authors have no conflict of interests to declare.

\section{References}

1. Ross N, John M, William B, Kazi MA, Peter R, et al.(1998) Arsenic poisoning of Bangladesh groundwater. Nature 395: 338.

2. José MC, Castiñeira M (1997) Oxidative stress, mitochondrial respiration and glycemic control: Clues from chronic supplementation with $\mathrm{Cr}^{3+}$ or $\mathrm{As}^{3+}$ to male Wistar rats. Nutrition 13: 965-970.

3. Kaleem M, Kirmani D, Asif M, Ahmed Q, Bano B (2006) Biochemical effects of Nigella sativa $\mathrm{L}$ seeds in diabetic rats. Ind J Exp Biol 44: 745-748. 
Citation: Parveen S, Molla SH, Ghosh TK, Chattopadhyay A (2017) Protection from Arsenic Induced Hyperglycemia by a Traditional Plant - A Preliminary Study. Hepatol Pancreat Sci 1: 102.

4. Ragavan B, Krishnakumari S (2006) Antidiabtic effect of T. arjuna bark extract in alloxan induced diabetic rats. Ind. J Clin Biochem 21: 123-128.

5. Bailey CJ, Day C (1989) Traditional plant medicines as treatment for diabetes. Diabetes Care 12: 553-564.

6. Shukla R, Sharma SB, Puri D, Prabhu KM, Murthy PS (2000) Medicinal plants for treatment of diabetes mellitus. Ind J Clin Biochem 15: 169-177.

7. Devi VD, Asna U (2008) Hypoglycemic potential of Morus indica. L and Costus igneus. Nak.- A preliminary study. Ind. J Exp Biol 46: 614-616.

8. Akhila JS, Divya C, Rejeesh, Vinod N, Maria K, et al. (2010) Effect of the insulin plant (Costus igneus) leaves on dexamethasone-induced hyperglycemia. Int $\mathrm{J}$ Ayurveda Res 1: 100-102.

9. Polter SJ, Caraballo AA, Lee YP, Eng WW, Gan HM, et al.(2015) Isolation, identification, whole-genome sequencing and annotation of four Bacillus species, $B$. anthracis RIT375, B. circulans RIT379, B. altitudinis RIT380 and $B$. megaterium RIT381, from internal stem tissue of the insulin plant Costus igneus. Genome Announc 3: e00847-15.

10. Prakash $\mathrm{KH}$, Harini AR, Prasanna NR (2014) A review on insulin plant (Costus igneus Nak). Pharmacogn Rev 8: 67-72.

11. Hardikar MR, Varma ME, Kulkarni AA, Kulkarni PP, Joshi BN (2016) Elucidation of hypoglycemic action and toxicity studies of insulin-like protein from Costus igneus. Phytochemistry 124: 99-107.

12. North DW, Gibb HJ, Abernathy CO (1997) Arsenic: Past, present and future considerations ( $1^{\text {st }}$ edn) Chapman and Hall, London.

13. Mukherjee S, Das D, Darbar S, Mitra C (2003) Dietary intervention affects arsenic-generated nitric oxide and reactive oxygen intermediate toxicity in islet cells of rats. Current Science 85(6): 786-793.

14. Debrup C, Avinaba M, Sourav S, Avijit P, Samrat G, et al.(2012) [6]-Gingerol isolated from ginger attenuates sodium arsenite induced oxidative stress and plays a corrective role in improving insulin signaling in mice. Toxicol Lett 210: 34-43.

15. Huggett AS, Nixon DA (1957) Use of glucose oxidase, peroxidase and O-dianisidine in determination of blood and urinary glucose. Lancet 273(6991): 368-370.

16. John BH, Gerald K (1961) An automated determination of glucose utilizing a glucose oxidase-peroxidase system. J Lab Clin Med 57: 970-980.
17. Das D (1981) Statistics in biology and psychology (3 $3^{\text {rd }}$ edn.) Academic Publishers, Calcutta.

18. Mana SC, Fatt NT, Ashraf MA (2016) The fate and transport of arsenic species in the aquatic ecosystem: A case study on Bestari Jaya, Peninsular Malaysia. Environ Sci Pollut Res Intl, pp: 1-9.

19. Bhattacharya S (2016) Medicinal plants and natural products in amelioration of arsenic toxicity: A short review. Pharm Biol 55: 349-354.

20. Kumar A, Rahman MS, lqubal MA, Ali M, Niraj PK, et al. (2016) Ground water arsenic contamination: A local survey in India. Int J Prev Med 7: 100-105.

21. Lai MS, Hseuh YM, Chen CJ, Shyu MP, Chen SY, et al. (1994) Ingested inorganic arsenic and prevalence of diabetes mellitus. Am J Epidemiol 139: 484-492.

22. Rahman M, Tondel M, Ahmed SA, Axelson O (1998) Diabetes mellitus associated with arsenic exposure in Bangladesh. Am J Epidemiol 148: 198203.

23. Tseng CH, Tai TY, Chong CK, Tseng CP, Lai MS, et al. (2000) Long term arsenic exposure and incidence of non-insulin dependent diabetes mellitus: a cohort study in arseniasis - hyperendemic village in Taiwan. Environ Health Perspect 108: $847-851$.

24. Kalailingam P, Kannaian B, Tamilmani E, Kaliaperumal R (2014) Efficacy of natural diosgenin on cardiovascular risk, insulin secretion and beta cells in streptozotocin (STZ)-induced diabetic rats. Phytomedicine 21: 1154-1161.

25. Hegde PK, Rao HA, Rao PN (2014)A review on insulin plant (Costus igneus Nak). Pharmacogn Rev 8: 67-72.

26. William F, Lakshminarayanan S, Chegu H (1993) Effect of some Indian vegetables on glucose and insulin in diabetic subjects. Int J Food Sci Nutr 44: 191-195.

27. Yang B, Fu J, Zheng H, Xue P, Yarborough K, et al.(2012) Deficiency in the nuclear factor E2-related factor 2 renders pancreatic $\beta$-cells vulnerable to arsenic-induced cell damage. Toxicol Appl Pharmacol 264: 315-323.

28. Dávila-Esqueda ME, Morales JM, Jiménez-Capdeville ME, De la Cruz E, Falcón-Escobedo R, et al. (2011) Low-level sub chronic arsenic exposure from prenatal developmental stages to adult life results in an impaired glucose homeostasis. Exp Clin Endocrinol Diabetes 119: 613-617. 